\title{
血液一部再循環回路を用いた減へパリン透析
}

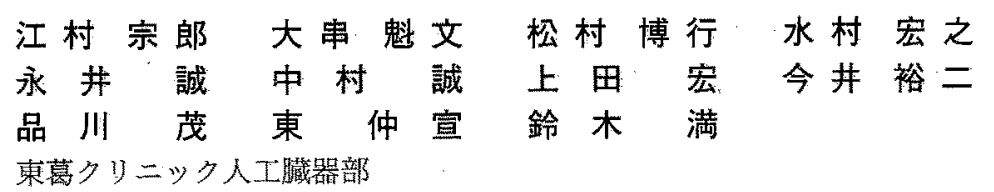

(昭和 59 年 3 月 3 日受付)

key words: partial blood recirculation circuit, low-heparin-dose hemodialysis, non-heparinization hemodialysis, shear rate

〈要旨〉

術後の出血や, 出血傾向を伴った慢性腎不全症例に対し, 透析中のヘパリン使用量の減少を目的として, 血液を一 部再循環させる回路を作成し，実際に臨床応用し検討した。

回路は一般に使用されている透析用回路の静脈側 chamber 下の流路を分岐させ,一方を outlet へ, 他方を動脈側 chamber 手前で合流させるように工夫したもので, 血液を一部再循環させることで, dialyzer 部分の血流量を 300 $\sim 400 \mathrm{ml} / \mathrm{min}$ に保ち, 流速を早めることで疑固を阻止するものである. 今回, 5 症例に対し減へパリン透析 35 回, 3 症例に対し無へパリン透析 14 回施行し比較検討した。

減ヘパリン透析では通常 3,000 10,000 単位のヘパリン使用症例に対し 300 1, 200 単位まで減少させることがで きたが, 施行中に凝固はなく, かつ返血もほほ完全で dialyzer 回路を含めた残血量は $1 \sim 4 \mathrm{ml}$ 程度であった. 無へ パリン透析では動脈側, 静脈側 chamber や dialyzer header 部に多少の凝固を認めたが, 中空糸内の凝固はほとんど なかった，また，減ヘパリン，無ヘパリン透析は各種の dialyzer により凝固に多少の変化がみられた.

以上, 一部再循環回路使用による減ヘパリンおよび無ヘパリン透析は, 残血量も少なく, 安全かつ簡単に行え有効 であった.

\section{Hemodialysis with low-dose heparinization via apartial blood recirculation circuit}

Muneo Emura, Yasufumi Ohkushi, Hiroyuki Matsumura, Makoto Nagai, Hiroshi Ueda, Yuji Imai, Shigeru Shinagawa, Nakaji Azuma, M. D., Mitsuru Suzuki, M. D.

Department of Artificial Organs, Tokyo Tokatsu Clinic

Recently, a wide variety of anticoagulants have been developed and are being applied after surgical operations and for hemodialysis in patients with hemorrhagic conditions. Their use entails much difficulty, however, because of problems concerning methods of administration, cost, etc. which are yet to be resolved. We have devised and clinically tried a hemodialysis circuit involving a partial blood recirculation pathway, designed for reduction in dose or elimination of the use of heparin, with gratifying results.

The partial blood recirculation circuit consists of a bifurcation of the route on the side of venous $(V)$ chamber, one leading to the outlet and the other for confluence with the stream just distal to the arterial (A) chamber so that the blood could flow faster, at a rate of $300-400 \mathrm{ml} / \mathrm{min}$, only within the dialysis unit to prevent blood clotting. This procedure was carried out on 49 occasions in 8 patients, 5 for low-dose heparinization and 3 for non -heparinization.

In low-heparin-dose hemodialysis a substantial heparin dose reduction in the to 300 to 1,200 units, compared

江村 宗郎 東葛クリニック人工臓器部

于 271 松戸市樋野口 822（0473-64-5121） 
with the usual dose of 3,000 to 10,000 units, was achieved without any clot formation and with a practically complete return of the blood. Residual blood was as little as 1 to $4 \mathrm{ml}$ throughout the extracorporeal circuit including the dialyzer and recirculation pathway. In the non-heparinization hemodialysis, on the other hand; some blood clots were detected in the chambers on both the $A$ and $V$ sides and in the dialyzer header but virtually none within the lumina of hollow fibers. The incidence and degree of blood coagulation varied more or less with the type of dialyzer.

Hemodialysis with a partial blood recirculation circuit with low-dose or non-heparinization proved to be a safe, simple, effective procedure with only a small amount intracircuit residual blood.

\section{緒言}

最近 prostaglandin や gabexate mesilate (FOY) 等 の抗凝固剂が開発され，術後や出血を伴った症例の透析 に用いられているが，使用方法が煩雑であることや高価 であることからまだ一般化された方法にはなり得ていな ঋ.

我々は HFK 中空系内 shear rate を高め, dialyzer 内 凝固を阻止する目的で血液を一部再循環できる回路を試 作し，隇へパリンおよび無へパリン透析を施行し良好な 結果を得たので報告する。

\section{方法}

図 1 は血液一部再循環回路図である。この回路は一般 记使用されている透析用血液回路の静脈側: chamber 下 の流路を分岐させ，一方を outlet へ他方を再循環ポンプ を介して動脈側 chamber 手前で合流させるようにした もので, 血液の流れは blood accessより血液ポンプに よって導びかれた血液 $\mathrm{X} \mathrm{m} l / \mathrm{min}$ が, 動脈側 chamber 手前で再循環ポンプによって導びかれた血液 $\mathrm{Y} \mathrm{m} l / \mathrm{min}$ と合流し, $\mathrm{X}+\mathrm{Y} \mathrm{m} l / \mathrm{min}$ の血流量となり, 動脈側 chamber, dialyzer 静脈側 chamber と流れ，静脈側 chamber 下で, blood accessにもどる血液 X $\mathrm{m} l / \mathrm{min}$ と再循環ポ ンプに導びかれる血液 $\mathrm{Y} \mathrm{m} l / \mathrm{min}$ に分加れる，このよう に dialyzer 部分のみ血液流速をはやめられるようにし た回路である。な扮回路内充買量は $130 \mathrm{~m} l$ であり，一般 の回路とかわらない。

また，透析装置は通常使用する装置のほ加に血液ポン プ (再循環ポンプとして使用) 1 台と圧メーター（動脈 側の圧を測定）があれば施行できる。

今回この回路を用いて隇ヘパリンおよび無へパリン透 析を施行した 8 症例表 1 に示した。 $1 \sim 5$ 0症例に減 ヘパリン透析， $6 \sim 8$ の症例に無ヘパリン透析を施行し た。

\section{結果}

表 2 に各症例が従来の透析時に使用していたへパリン 量, 血液一部再循環回路を用いた時のへパリン量, dialyzer 入口血流量 (送血量十再循環血液量), dialyzer 回 路を含めた残血量（へモグロビン法）㜿よび使用した dialyzer を示した.

隇へパリン透析 5 症例では, 従来 3,000 10,000 単位 のへパリンを使用していたが，この回路を用いた透析で は，300 1,200 単位まで減少できた。しか施行時に凝 固例はなく，残血量も従来の透析時とほとんどかわらな

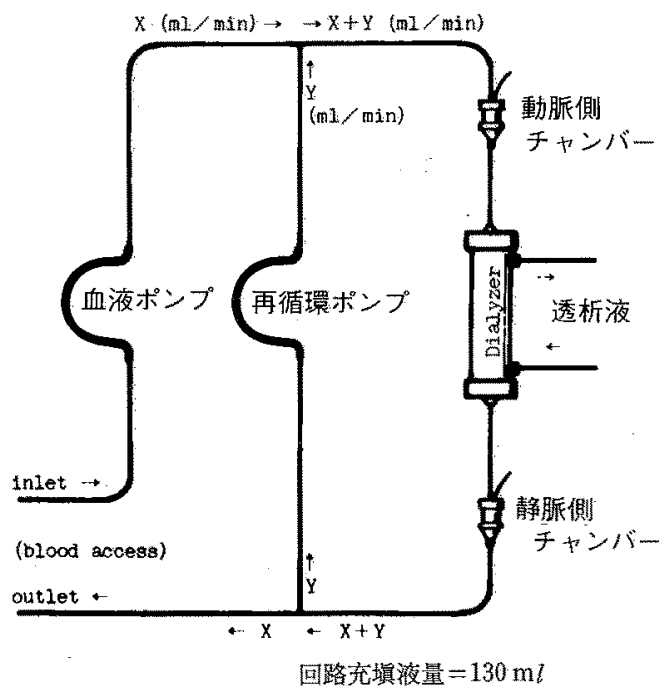

図 1 血液一部再循環回路図

\begin{tabular}{|c|c|c|c|c|c|}
\hline 症例 & 性別 & 年齢 & 透析歴 & 施行理由 & 施行回数 \\
\hline 1 & 男 & 52 & 10年 3 力月 & 出 血 & 19 \\
\hline 2 & 男 & 76 & 1 年 6 为月 & 出 血 & 6 \\
\hline 3 & 女 & 39 & 8 年 4 力月 & 術 後 & 4 \\
\hline 4 & 女 & 63 & 6 力月 & 術 後 & 3 \\
\hline 5 & 男 & 35 & 1力月 & 出 血 & 3 \\
\hline 6 & 男 & 59 & 2 年 5 力月 & 出 血 & 7 \\
\hline 7 & 女 & 26 & 3 年 2 为月 & 出 血 & 4 \\
\hline 8 & 女 & 75 & 3 为月 & 術 後 & 3 \\
\hline
\end{tabular}

表 1 隇ヘパリン，無ヘパリン透析施行症例 


\begin{tabular}{c|c|c|c|c|c}
\hline 症例 & $\begin{array}{r}\text { 通常透析時 hep 量 } \\
(\mathrm{U})\end{array}$ & $\begin{array}{r}\mathrm{RC} \text { 回路使用時 hep 量 } \\
(\mathrm{U})\end{array}$ & $\begin{array}{r}\text { Dialyzer 入口血流量 } \\
(\mathrm{ml} / \mathrm{min})\end{array}$ & $\begin{array}{c}\text { 残 血 量 } \\
(\mathrm{ml})\end{array}$ & Dialyzer \\
\hline 1 & 10,000 & $1,189+45$ & $358+19$ & $1.73+0.69$ & $\mathrm{~B} 1-70, \mathrm{~B} 1-100, \mathrm{AM}-10$ \\
\hline 2 & 8,000 & $1,150+84$ & $375+20$ & $2.60+0.50$ & $\mathrm{~B} 2-95, \mathrm{TF}-160$ \\
\hline 3 & 6,000 & $388+384$ & $365+6$ & $3.19+1.17$ & $\mathrm{CF}-1211$ \\
\hline 4 & 3,000 & $597+140$ & $350+0$ & $0.77+0.29$ & $\mathrm{AM}-10 \mathrm{~T}$ \\
\hline 5 & 7,000 & $700+60$ & $350+0$ & $2.88+0.63$ & $\mathrm{~B} 2-75$ \\
\hline 6 & 5,000 & 0 & $346+15$ & $4.10+0.88$ & $\mathrm{~B} 2-100$ \\
\hline 8 & 5,000 & 0 & $350+0$ & $4.74+0.28$ & $\mathrm{KF}-101-1.2$ \\
\hline
\end{tabular}

表 2 減ヘパリン, 無ヘパリン透析

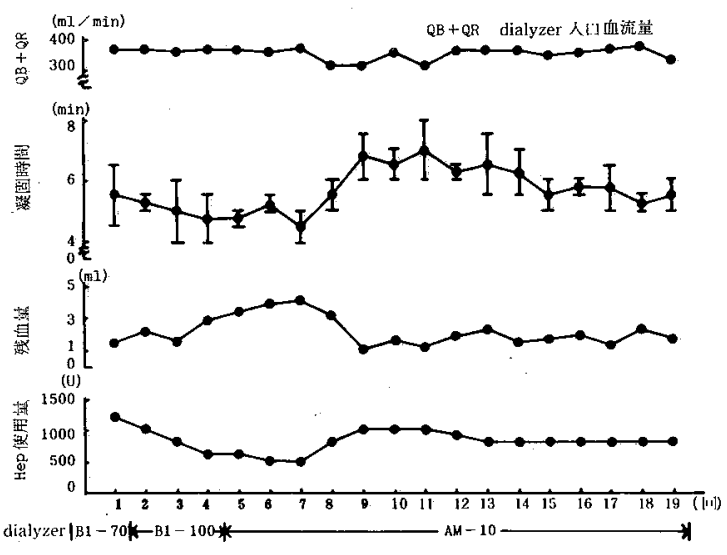

図 2 減ヘパリン透析（症例 1)

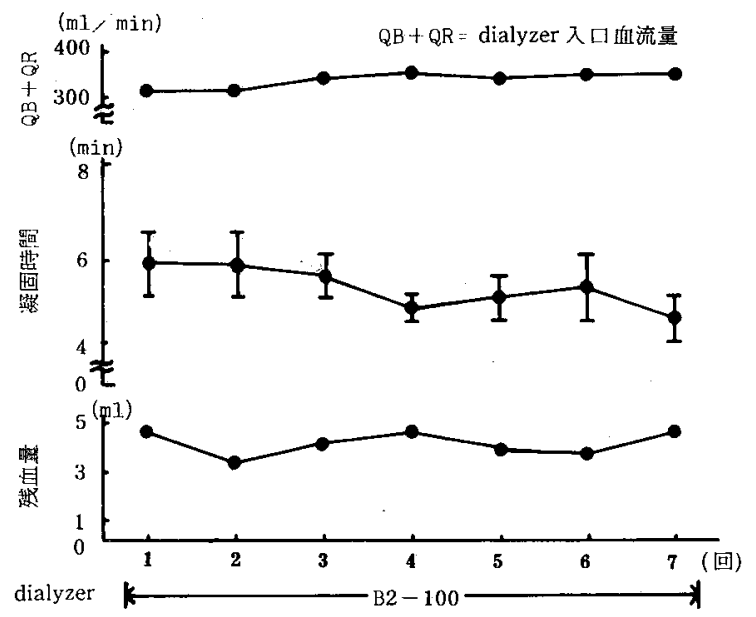

図 3 無ヘパリン透析（症例 6)

い値を示した.

無へパリン透析 3 症例では, 残血量が $4 \sim 5 \mathrm{~m} l$ と減へ パリン透析に比べ,やや増加した。 また肉眼的にも dial- yzer header 部や動・静脈側 chamber に少量凝固が認 められた。

図 2 , 図 3 に減へパリン透析を 19 回施行した症例 1 と 無へパリン透析を 7 回施行した症例 6 の各透析ごとのへ パリン使用量, 残血量, 凝固時間抢よび dialyzer 入口血 流量を示した。凝固時間はリーホワイト 1 本法で回路動 脈側にて測定した.

血液一部再循環回路でのヘパリン投与方法は，透析開 始 30 分間はまったく無へパリン状態で施行し，その後 15〜30 分ごとに凝固時間を測定し，透析前に測定した凝 固時間の \pm 1 分以内に維持できるようにへパリンを使用 した.

図 2 の減へパリン透析では 1 回目施行時 1,200 単位の ヘパリンを使用したが, その後徐々に使用量を減少させ, 7 回目では 500 単位しか使用しなかったが残血が多く なったため, 以後 1,000 単位前後のへパリン量で施行し, 残血量は前後で肉眼的にも問題なかった。

図 3 の症例は減へパリン透析を目的に 1 回目を施行し たところ，へパリンを使用せずに凝固時間が 5 分 30 秒 〜 6 分 30 秒の間に維持でき, 残血量は $4 \sim 5 \mathrm{~m} l$ であり, 肉眼的な残血も中空系部には注とんど認められなかった ため以後無へパリン透析を計 7 回施行したが, 凝固例は なかった.

\section{考察}

最近, 新たな抗凝固剂が開発され, その使用報告 ${ }^{1 \sim 4)}$ が なされている。しかし，それらの薬剤もそれ自身欠点を もっており，適応が限られたり，ヘパリンの補助剤にと どまったりしている.

ヘパリンは抗凝固剤として, 1918 年 Howell らにより 発見され，1943 年 Kolff ら ${ }^{5)}$ により回転ドラム型人工腎 を用いて臨床応用されてから現在まで透析療法に広く用 いられ，その役割は体外循環に使用する抗凝固郕として 欠かすことのできない薬剤となっている。 
しかし，術後や消化管出血等の high risk bleeding を 有する症例では，へパリン量を減少させた透析を施行し なければならない。

南部ら ${ }^{6)}$ は, ルーチン透析に最低限必要とするへパリ ン量は $3,456 \pm 273 \mathrm{u}$ であり, 特殊な回路を用いれば 1 , $200 \pm 125 \mathrm{u}$ まで使用量を減少できると報告している。今 回我及が作成した回路による隇へパリン透析施行群の使 用ヘパリン量は， $8,047 \pm 3,632 \mathrm{u}(\mathrm{n}=35.5$ 症例 $)$ であり, 抗凝固剤をまったく使用しない透析も 3 症例に計 14 回 施行できた。これは柴田ら ${ }^{7)}$ の報告のように中空糸内血 流速度を shear rate $400 \mathrm{sec}^{-1}$ に速めると透析膜表面へ の血球成分の付着が抑制されるためにへパリン量の減少 が可能だと思われる，つまり，血液の凝固は血小板の粘 着からはじまり，凝集を抗こし， dialyzer 回路の内表面 を反応の場として接触活性化され, 最終的にはフィブリ ンの形成に至るが，何らかの方法で血小板の粘着を阻止 できれば, 活性化された凝固因子は反応の場がなくなり, 体内で失活してしまうはずである。そこで中空糸内血流 量を多くとれば shear rateが大きくなり，血球成分の付 着が力学的に抑制され，抗血栓性が高まる.

shear rate の算出方法は dialyzer (HFK) の流路が内 管であるから次式より表わされる ${ }^{8)}$.

$$
\begin{aligned}
& \text { shear rate }=\frac{4 \mathrm{Q}}{\pi \mathrm{r}^{3}} \quad(\mathrm{sec}) \\
& \mathrm{Q}: \text { 中空系 } 1 \text { 本あたりの血流量 } \\
& \pi: \text { 月周率 } \\
& \mathrm{r}: \text { 中空系の内半径 }
\end{aligned}
$$

すなわち, shear rate は血流量が同じであっても，中 空系の本数㧤よび内径によって左右される。よってルー

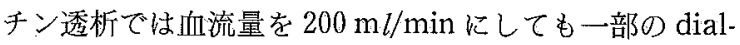
yzer を除きほとんどが shear rate $400 \mathrm{sec}^{-1}$ 以下であ り，抗凝固郕を使用しなければ，凝固する可能性が高い。

今回我々が作成した血液一部再循環回路では shear rateを自由に可変でき, 力学的に血球付着を抑制し, 抗 凝固剤をほとんど使用せずに安全かつ簡単に施行できる と考光る。

\section{まとめ}

1) 血液一部再循環回路を試作し, 減へパリンおよび 無へパリン透析を計 49 回施行した.
2 ）減へパリン透析では通常 $3,000 \sim 10,000$ 単位のへ パリン使用症例に対し，300 1,200 単位まで減少でき た。

3) 減へパリンおよび無へパリン透析施行中に凝固は なく, 残血量も $1 \sim 5 \mathrm{~m} l$ 程度であった。

4) 血液一部再循環回路使用による減へパリンおよび 無へパリン透析は残血も少なく, 安全加つ簡単に行光有 効であった。

\section{文献}

1）松井則明, 小沢 潔, 中村義弘, 秋葉 隆, 吉山直 樹, 中川成之輔, 武内重五郎：無ヘパリン透析用抗 凝固薬としてのプロスタグランジン $\mathrm{E}_{1}$ および $\mathrm{D}_{2}$ の有用性について。人工臟器, $10: 245-248,1981$.

2）森河 浄，田村克彦，児島弘臣，高橋淳子，衣笠元 りこ, 関口 孝, 中村文義, 高橋 健, 秋沢忠男, 佐藤昌志, 北岡建樹, 出浦照国, 越川昭三, 藤井節 郎: 蛋白分解酵素阻害剂 FUT-175 の血液透析への 応用. 人工藏器, $12: 75-78,1983$.

3）松井則明, 中西太一, 馬場 操, 篠田俊雄, 中川成 之輔, 武内重五郎：合成トロンビン薬 MD 805 単独 による血液透析の経験. 人工臟器, $11: 525-528$, 1982.

4）井上通泰, 高田 宏, 高橋 進 : 抗凝固法の再検討 一へパリン以外の抗凝固薬の有用性と限界. 透析会 誌, $15 ： 417,1982$.

5) Kolff, W. J., and Berk, H.T.J : The artifical kidney, dialyzer with great area, geneesk, gidds 5 : 21, 1943.

6) 南部正人, 草刈修一, 今井了, 長岡京子, 松橋茂 子，高田美幸，川口純子，笠木正明，酒井 紏：へ パリン化法における評価と限界. 透析会誌, 15(4)： 407-408, 1982.

7）柴田 猛, 蟹由 斉, 大坂守明, 二瓶 宏, 三村信 英：流体力学的面加らの抗凝固性の検討. 透析会誌, 15 (4) : 410, 1982.

8）萩原文二, 橋本光一：限外濾過法, 膜による分離法, p. 94, 講談社, 1974 . 